Original Research Article

\title{
Undergraduate medical students' perception regarding computer assisted learning in experimental pharmacology practical
}

\author{
Manish Kumar ${ }^{1}$, Manish Kumar ${ }^{2}$, Hitesh Mishra ${ }^{1}$, Pramod Kumar Manjhi ${ }^{3}$, Akash Chandra ${ }^{1}$, \\ Lalit Mohan $^{1 *}$, Harihar Dikshit ${ }^{1}$
}

\begin{abstract}
${ }^{1}$ Department of Pharmacology, ${ }^{2}$ Department of Physiology, Indira Gandhi Institute of Medical Sciences, Patna, Bihar, India

${ }^{3}$ Department of Pharmacology, Heritage Institute of Medical Sciences, Varanasi, Uttar Pradesh, India
\end{abstract}

Received: 05 January 2018 Accepted: 29 January 2018

*Correspondence to:

Dr. Lalit Mohan,

Email:manu072@gmail.com

Copyright: (C) the author(s), publisher and licensee Medip Academy. This is an openaccess article distributed under the terms of the Creative Commons Attribution NonCommercial License, which permits unrestricted noncommercial use, distribution, and reproduction in any medium, provided the original work is properly cited.

\begin{abstract}
Background: Main objective of this study was to find out the students' perception and to obtain feedback towards the use of Animal Simulator to demonstrate drug effects in terms of its acceptability, advantages and disadvantages of Computer Assisted Learning (CAL) in experimental pharmacology practical as an educational tool.

Methods: Questionnaire based study, done on randomly and voluntarily selected ninety-six fourth and fifth semester MBBS Students. Divided into four groups and each group contained 24 students. Students were taught experimental pharmacology practical online using Animal simulator (CAL- Computer Assisted Learning) for 2 hours on different days in three sessions. Questions and their feedback was taken during these sessions and presented in tables. Statistical analysis of data was done using Graph Pad software.

Results: Majority of students i.e. $64(66.67 \%)$ agreed that in vitro and in vivo experiments on animals are essential for better understanding and learning of the biological process. Students were agreed to the majority of the statements for CAL like enjoyable and time saving, easy to perform, contributes more to understanding theoretical concepts, no experimental error seen, welcome change and best alternative to laboratory practical and many experiments can be demonstrated in a short time. Students were disagreed on statements like CAL is an effective method of teaching practical aspects and preferred experimentation than laboratory practical. Majority of students given yes/positive response to questions showing advantages of using CAL. Also, positive feedback was obtained regarding questions showing disadvantages of using CAL software.

Conclusions: Students' perception regarding practical with CAL laboratory using animal simulator was good. The overall view was expressed that they found the exercises interesting and educationally beneficial. Computer assisted learning is a feasible and very effective teaching and learning method in pharmacology with huge potential to change the way of learning as it meets the majority of the learning objectives.
\end{abstract}

Keywords: Animal simulator, Computer assisted learning, Experimental pharmacology practical

\section{INTRODUCTION}

At the undergraduate level, pharmacology is mainly taught to second year medical students in India and the subject is horizontally integrated with certain basic science subjects like microbiology, pathology and forensic medicine. ${ }^{1}$
Experimental pharmacology in which, demonstration of drug effects on tissues or on whole animal is an integral and essential part of practical pharmacology teaching for undergraduate medical students. ${ }^{2,3}$ Though such demonstrations are time honored and effective, certain limitations exist. Lack of ready availability of animals, 
cost of purchasing and maintaining them are major constraints in many institutions. Large animals like dog and cat are difficult to handle during demonstrations in the laboratory. ${ }^{2}$

Also, it requires the usage of a large number of animals and a lot are sacrificed during each experiment even for studying and demonstrating the action of drugs which are already established. ${ }^{4}$

People for the Ethical Treatment of Animals (PETA) pressure lead to stop animal dissection in Indian's top university and governing body is making sure that students use the most modern education tools possible, meaning computer models over animals, says PETA India. The students of Life Sciences across the country will now be able to learn without being forced to hurt and kill animals in the practical classroom. ${ }^{5}$

PETA opposes animal testing-whether toxicity testing, basic or applied research, or for education and training-on both moral and practical grounds. The group also believes that it is wasteful, unreliable, and irrelevant to human health, because artificially induced diseases in animals are not identical to human diseases. They say that animal experiments are frequently redundant and lack accountability, oversight, and regulation. They promote alternatives, including embryonic stem cell research and in vitro cell research. ${ }^{6}$

Medical council of India (MCI) had gazette notification on date 18 March 2014 for teaching Physiology and Pharmacology in Undergraduate curriculum the required knowledge and skill should be imparted by Software programs for Computer Assisted Learning (CAL) have been designed by some of the pharmacology departments to overcome animal experiment limitations. These programs mimic the actual experimental set up in the laboratory. ${ }^{7}$

Software programs for Computer Assisted Learning (CAL) have been designed by some of the pharmacology departments to overcome these limitations. These programmes mimic the actual experimental set up in the laboratory. ${ }^{2}$

The main objective of this study was to find out the students' perception and to obtain feedback towards the use of Animal Simulator to demonstrate drug effects in terms of its acceptability, advantages and disadvantages of Computer Assisted Learning (CAL) in experimental pharmacology practical as an educational tool. It will be helpful in modifying undergraduate pharmacology teaching pattern.

\section{METHODS}

Study was carried out at Pharmacology Department, IGIMS, Patna.
Duration of study were two months and it was questionnaire study.

Ninety-six (96) fourth and fifth semester MBBS Students were randomly selected and divided into four groups. Each group contained 24 students. Students were taught experimental pharmacology practical online using Animal simulator for 2 hours on different days. This study was approved from Institutional Ethics Committee of IGIMS, Patna.

Online animal simulator was used in the three sessions for the same batch of medical students undergoing pharmacology course. Experimentation was performed on 12 desktops in CAL laboratory of Department of Pharmacology, IGIMS, Patna. Experiments performed were effect of drugs on isolated frog heart, ocular effects of miotics and mydriatics in rabbit eye and DRC of different drugs on frog's rectus abdominis muscle. The acceptability, advantages and disadvantages of using CAL as an educational tool were assessed after each session.

In $1^{\text {st }}$ session students were asked to complete a questionnaire (Annexure I), which consisted of two parts. The first part had collected demographic and other relevant information about the student respondents. The sex and nationality of the respondents had been noted. The second part of the questionnaire consists of 11 statements regarding student's point of view of online experimental pharmacology practical using Animal simulator. The students were asked to score each individual statement using the following key. The students were instructed to use whole numbers only.

- $\quad 1$ - Strongly disagrees

- 2- Disagree,

- 3- No opinion,

- 4- Agree and 5- Strongly

In $2^{\text {nd }}$ session the students were asked 6 questions (Annexure II) to list the advantages and in $3^{\text {rd }}$ session the students were asked 10 questions (Annexure III) to list the disadvantages of using CAL software to demonstrate drug effects as an educational tool for practical classes in pharmacology (open ended questions). ${ }^{2,8}$ In order to facilitate free expression of ideas, students were asked to omit their names while answering these questions. The questionnaire to be used in the study was shown in the Appendix I for $1^{\text {st }}$ session, Appendix II for $2^{\text {nd }}$ session and Appendix III for $3^{\text {rd }}$ session.

Students were informed that their participation in this study will be voluntary. The questionnaire prepared was based on previous studies, which has assessed the reliability of questionnaire and discussion with faculty members of Department of Pharmacology, IGIMS, Patna. ${ }^{2,8}$ 


\section{Statistical analysis}

Feedback obtained from students were presented in tables. Statistical analysis of data was done using Graph Pad software.

\section{RESULTS}

Questionnaires were distributed to 96 students. Feedback obtained from the students is presented in Tables 1, 2, 3 and 4. Table 1 contained demographic details. In the questionnaire given to students in session 1 and 2 the acceptability of CAL as a method of demonstrating drug effects is clearly shown. Large majority of students have expressed the advantages such as avoid in use of animals, clear visualization of drug effects (Table 3 ).

Table 1: Demography.

\begin{tabular}{|lll|}
\hline & $\begin{array}{l}\text { Number of student } \\
(\mathbf{n = 9 6 )}\end{array}$ & $\begin{array}{l}\text { Percentage } \\
(\%)\end{array}$ \\
\hline Male & 49 & $51 \%$ \\
\hline Female & 58 & $59 \%$ \\
\hline
\end{tabular}

Table 2: Student's point of view of online experimental pharmacology practical using animal simulator.

\begin{tabular}{|c|c|c|c|c|c|}
\hline \multirow[b]{2}{*}{ Statements } & \multicolumn{5}{|c|}{ Response (\%) (n=96) } \\
\hline & $\begin{array}{l}\text { Strongly } \\
\text { disagree (1) }\end{array}$ & $\begin{array}{l}\text { Disagree } \\
(2)\end{array}$ & $\begin{array}{l}\text { No opinion } \\
\text { (3) }\end{array}$ & Agree (4) & $\begin{array}{l}\text { Strongly } \\
\text { agree (5) }\end{array}$ \\
\hline $\begin{array}{l}\text { In vitro and/or in vivo experiments in animals } \\
\text { are essential for better understanding and } \\
\text { learning of the biological process }\end{array}$ & $10(10.42 \%)$ & $\begin{array}{l}14 \\
(14.58 \%)\end{array}$ & $8(8.33 \%)$ & $36(37.5 \%)$ & $\begin{array}{l}28 \\
(29.17)\end{array}$ \\
\hline $\begin{array}{l}\text { Computer simulation is more enjoyable and } \\
\text { time saving than laboratory practical }\end{array}$ & $5(5.21 \%)$ & $\begin{array}{l}15 \\
(15.63 \%)\end{array}$ & $13(13.54 \%)$ & $\begin{array}{l}45 \\
(46.88 \%)\end{array}$ & $\begin{array}{l}18 \\
(18.75 \%)\end{array}$ \\
\hline $\begin{array}{l}\text { Computer simulation is easy to perform than } \\
\text { laboratory practical }\end{array}$ & 0 & 0 & $9(9.38 \%)$ & $\begin{array}{l}57 \\
(59.38 \%)\end{array}$ & $\begin{array}{l}30 \\
(31.25 \%)\end{array}$ \\
\hline $\begin{array}{l}\text { CAL is an effective method of teaching practical } \\
\text { aspects }\end{array}$ & $4(4.17 \%)$ & $\begin{array}{l}21 \\
(21.87 \%)\end{array}$ & $\begin{array}{l}24 \\
(25 \%)\end{array}$ & $\begin{array}{l}40 \\
(41.67 \%)\end{array}$ & $\begin{array}{l}7 \\
(7.29 \%)\end{array}$ \\
\hline $\begin{array}{l}\text { Computer simulation contributes more to } \\
\text { understanding theoretical concepts viz. Terms, } \\
\text { dose and concentration than laboratory practical }\end{array}$ & $2(2.08 \%)$ & $\begin{array}{l}27 \\
(28.13 \%)\end{array}$ & $10(10.42 \%)$ & $\begin{array}{l}39 \\
(40.63 \%)\end{array}$ & $\begin{array}{l}18 \\
(18.75 \%)\end{array}$ \\
\hline $\begin{array}{l}\text { In computer simulation no experimental error } \\
\text { are seen as in laboratory practical }\end{array}$ & $3(3.13 \%)$ & $\begin{array}{l}13 \\
(13.54 \%)\end{array}$ & $17(17.71 \%)$ & $\begin{array}{l}18 \\
(18.75 \%)\end{array}$ & $\begin{array}{l}45 \\
(46.88 \%)\end{array}$ \\
\hline $\begin{array}{l}\text { I would prefer to have done the experiment with } \\
\text { computer simulation than laboratory practical }\end{array}$ & $9(9.38 \%)$ & $\begin{array}{l}30 \\
(31.25 \%)\end{array}$ & $13(13.54 \%)$ & $\begin{array}{l}39 \\
(40.63 \%)\end{array}$ & $\begin{array}{l}5 \\
(5.21 \%)\end{array}$ \\
\hline CAL is a welcome change to routine practicals & $4(4.17 \%)$ & $\begin{array}{l}9 \\
(9.38 \%)\end{array}$ & $26(27.08 \%)$ & $\begin{array}{l}57 \\
(59.38 \%)\end{array}$ & 0 \\
\hline $\begin{array}{l}\text { Computer simulation is the best alternative to } \\
\text { laboratory practical }\end{array}$ & $2(2.08 \%)$ & $\begin{array}{l}8 \\
(8.33 \%)\end{array}$ & $35(36.46 \%)$ & $\begin{array}{l}44 \\
(45.84 \%)\end{array}$ & $\begin{array}{l}7 \\
(7.29 \%)\end{array}$ \\
\hline $\begin{array}{l}\text { Effects of drugs demonstrated on animals like } \\
\text { frogs and rabbits are interesting }\end{array}$ & $5(5.21 \%)$ & $\begin{array}{l}9 \\
(9.38 \%)\end{array}$ & $17(17.71 \%)$ & $\begin{array}{l}52 \\
(54.17 \%)\end{array}$ & $\begin{array}{l}13 \\
(13.54 \%)\end{array}$ \\
\hline $\begin{array}{l}\text { Many experiments can be demonstrated in a } \\
\text { short time }\end{array}$ & 0 & $\begin{array}{l}5 \\
(5.21 \%)\end{array}$ & 0 & $\begin{array}{l}57 \\
(59.38 \%)\end{array}$ & $\begin{array}{l}34 \\
(35.42 \%)\end{array}$ \\
\hline
\end{tabular}

The disadvantages pointed out by them include lack of interaction with living tissues and dependence on computer (Table 4).

Analysis showed that the majority i.e. $64(66.67 \%)$ students agreed that in vitro and in vivo experiments in animals are essential for better understanding and learning of the biological process. $24(25 \%)$ students expressed opinion against use of experimental animals and also raised the issue of ethical conduct in such work. A minority of $8(8.33 \%)$ students were undecided on this view (Table 2).

\section{DISCUSSION}

The results of this study convey the readiness of most medical students to use animals for learning and research. But in a significant percentage, the attitude towards animal experiments was contrary i.e. one third (33.33\%) of medical students were neutral or opposed to vivisection as a teaching tool and two third $(66.67 \%)$ were agreed that in vitro and/or in vivo experiments in animals are essential for better understanding and learning of the biological process. These findings were similar to a study done in a medical school of Israel where $59 \%$ of students expressed 
a positive attitude, $13.5 \%$ were neutral and $27.5 \%$ saw the laboratory use of animals negatively. ${ }^{9}$

\section{Table 3: Feedback obtained from students regarding advantages of using CAL software to demonstrate drug effects by stating YES or NO.}

\begin{tabular}{|lll|}
\hline Statement & \multicolumn{2}{l|}{ Response (\%) $(\mathbf{n = 9 6 )}$} \\
\hline YES & NO \\
\hline $\begin{array}{l}\text { Avoids use of animals } \\
\text { visualised clearly }\end{array}$ & $96(100 \%)$ & 0 \\
\hline $\begin{array}{l}\text { Exercises difficult to be } \\
\text { conducted in the } \\
\text { laboratory can be } \\
\text { demonstrated using }\end{array}$ & $91(86.46 \%)$ & $13(13.54 \%)$ \\
\begin{tabular}{l} 
CAL \\
\hline $\begin{array}{l}\text { Many students can } \\
\text { observe experiments at } \\
\text { the same time }\end{array}$
\end{tabular} & $87(90.63 \%)$ & $9(5.21 \%)$ \\
\hline $\begin{array}{l}\text { Experiments can be } \\
\text { observed repeatedly } \\
\text { without loss of animals }\end{array}$ & $96(100 \%)$ & 0 \\
\hline $\begin{array}{l}\text { No experimental errors } \\
\text { are seen as in } \\
\text { laboratory exercises }\end{array}$ & $61(63.54 \%)$ & $35(36.46 \%)$ \\
\hline
\end{tabular}

Table 4: Feedback obtained from students regarding disadvantages of using CAL software to demonstrate drug effects by stating YES or NO.

\begin{tabular}{|c|c|c|}
\hline \multirow{2}{*}{ Statement } & \multicolumn{2}{|c|}{ Response (\%) } \\
\hline & YES & NO \\
\hline $\begin{array}{l}\text { No direct interaction with } \\
\text { living tissue }\end{array}$ & $\begin{array}{l}87 \\
(90.63 \%)\end{array}$ & $\begin{array}{l}9 \\
(9.37 \%)\end{array}$ \\
\hline $\begin{array}{l}\text { Fun of making observation is } \\
\text { missed }\end{array}$ & $\begin{array}{l}74 \\
(77.08 \%)\end{array}$ & $\begin{array}{l}22 \\
(22.92 \%)\end{array}$ \\
\hline May easily forget details & $\begin{array}{l}91 \\
(94.79 \%)\end{array}$ & $\begin{array}{l}5 \\
(5.21 \%)\end{array}$ \\
\hline $\begin{array}{l}\text { Experiment is programmed } \\
\text { with prefixed doses }\end{array}$ & $\begin{array}{l}91 \\
(94.79 \%)\end{array}$ & $\begin{array}{l}5 \\
(5.21 \%)\end{array}$ \\
\hline $\begin{array}{l}\text { Lack of interaction with live } \\
\text { animals }\end{array}$ & $\begin{array}{l}78 \\
(81.25 \%)\end{array}$ & $\begin{array}{l}18 \\
(18.75 \%)\end{array}$ \\
\hline $\begin{array}{l}\text { Experiments performed in } \\
\text { laboratory are easier to } \\
\text { remember }\end{array}$ & $\begin{array}{l}74 \\
(77.08 \%)\end{array}$ & $\begin{array}{l}22 \\
(22.92 \%)\end{array}$ \\
\hline $\begin{array}{l}\text { Variations in response as } \\
\text { observed in living tissue } \\
\text { cannot be observed }\end{array}$ & $\begin{array}{l}74 \\
(77.08 \%)\end{array}$ & $\begin{array}{l}22 \\
(22.92 \%)\end{array}$ \\
\hline $\begin{array}{l}\text { Requires expertise to handle } \\
\text { problems related to computers }\end{array}$ & $\begin{array}{l}65 \\
(67.71 \%)\end{array}$ & $\begin{array}{l}31 \\
(32.29 \%)\end{array}$ \\
\hline Expensive method of teaching & $\begin{array}{l}57 \\
(59.38 \%)\end{array}$ & $\begin{array}{l}39 \\
(40.62 \%)\end{array}$ \\
\hline $\begin{array}{l}\text { Practical knowledge of how to } \\
\text { do the experiment is lost }\end{array}$ & $\begin{array}{l}83 \\
(86.46 \%)\end{array}$ & $\begin{array}{l}13 \\
(13.54 \%)\end{array}$ \\
\hline
\end{tabular}

In this study, students were not posed to a real-life situation, but questions were putted to simply test their outlook towards CAL Lab experiments using Animal Simulator. Significant number of students favoured animal use indicates that live experiments using animal will give better understanding and learning of the biological process and pharmacological actions of drugs. But this result was opposite to the previous study in which students were disagreed to do experimentations on animals due to concern regarding less efficacy in animal experimentation as well as mortality of animals. ${ }^{10}$

$65 \%$ of students were agreed that computer stimulation was more enjoyable and time saving than laboratory practical. $90 \%$ found that computer simulation was easy to perform with respect to laboratory practical. But $51 \%$ students were against the opinion that CAL is an effective method of teaching practical aspects. 59\% students had agreed that Computer simulation contributes more to understanding theoretical concepts viz. Terms, dose and concentration than laboratory practical. $65 \%$ had agreed that in computer simulation no experimental error was seen as in laboratory practical. But $54 \%$ were disagree with the statement that I would prefer to have done the experiment with computer simulation than laboratory practical. $59 \%$ were agreed to the statement that CAL is a welcome change to routine practical. $53 \%$ were agreed to the statement that Computer simulation is the best alternative to laboratory practical. $67 \%$ were agreed to the statement that effects of drugs demonstrated on animals like frogs and rabbits are interesting. 95\% were agreed to the statement that many experiments can be demonstrated in a short time. Results were similar to previous study. ${ }^{2}$

Majority of students given yes/positive response/answer to table 3 questions showing advantages of using CAL software to demonstrate drug effects. Positive feedback was obtained regarding table 4 questions showing disadvantages of using CAL software to demonstrate drug effects. Results were similar to previous study. ${ }^{2}$

Practical exercises in pharmacology fulfil certain educational objectives. Handling an animal and dissecting it helps to build the psychomotor skill of a student. On the other hand, it is not necessary that these experiments be carried out by the students "first-hand", if possible for a faculty member to demonstrate these experiments and let the students observe the results and interpret them. Computer Assisted Learning can be very useful in such a setting. CAL also offers a stimulus- variation from the routine teaching methodologies. Attempts have been made by many teachers of pharmacology to improve teaching methods. ${ }^{4,11-13}$

Conducting practical sessions using CAL software require planning. If the students adopted an interactive, selflearning mode the learning experience is far richer. But this calls for availability of computers to every student. While this is an ideal learning method with CAL software, many departments and institutions in this country may not be able to provide such a setting owing to cost-constraints. Therefore, we used this as a demonstration to the whole 
class. Small group teaching with simultaneous discussion may be a useful method for such demonstrations. Our feedback shows that students appreciated this as a welcome change to practical sessions involving demonstrations, routinely conducted in the laboratory. Since these students have been exposed to both methods (faculty conducted demonstrations of certain experiments and also the CAL software) their observations are valid and relevant. ${ }^{2}$

Reduction in expenses involved for animal experiments is a definitive advantage and dependence on computers and technical problems arising during class are possible disadvantages of this method. It is to be noted that $87 \%$ of students who attended session 1 suggested that CAL software should be used as an adjuvant to practical laboratory sessions. It is clear from this study that CAL software can be used as an acceptable method of teaching practical pharmacology demonstrations to students. Many studies have highlighted the usefulness of CAL. ${ }^{14-16}$

\section{CONCLUSION}

General impressions gained from students regarding practical with CAL laboratory using animal simulator was good. The overall view was expressed that they found the exercises interesting and educationally beneficial. Due to opposition by PETA and MCI regulations Computer Assisted Learning has gained huge potential to change the way of for animal experimentation as it meets the majority of the learning objectives as well as it is very effective and feasible. Teaching and learning in the field of medical curriculum is rapidly changing so that computer based learning methods have qualitative and quantitative potential to raise teaching standards.

Funding: No funding sources Conflict of interest: None declared

Ethical approval: The study was approved by the Institutional Ethics Committee of IGIMS, Patna

\section{REFERENCES}

1. Sudha J. Graduate training programmes in pharmacology in India. Health administrator. 2006;19(1):88-91.

2. Kuruvilla A, Ramalingam S, Bose AC, Shastri GV, Bhuvaneswari K, Amudha G. Use of Computer Assisted Learning as an Adjuvant to Practical Pharmacology Teaching: Advantages and Limitations. Indian Journal of Pharmacology. 2001;33:272-5.

3. Baby LT, Kavalakkat JC, Abraham S, Sathianarayanan S. CAL: A modern tool for pharmacology. (Computer Assisted Learning). The Internet Journal of Medical Simulation. 2009;2:62-4.

4. Kuruvilla A, Ernest K. Patient oriented problem solving system of teaching pharmacology, Indian Journal of Pharmacology. 1994;26(3):185-7.
5. PeTA INDIA. PETA Gets Set to Celebrate End of Animal Dissection in Indian Universities [homepage on the Internet]. c2011 [updated 2011 March 25]. Available at: https://www.petaindia.com/media/petagets-set-celebrate-end-animal-dissection-indianuniversities/

6. Animal Experiments: Overview, PETA, accessed June 30, 2010. Also see Rosenberg, Howard. Fighting tooth and claw, The Los Angeles Times, March 22, 1992.

7. The Gazette of India. Extraordinary. part III- Section 4. [No. 88]. New Delhi, Wednesday, March 19, 2014/Phalguna 28, 1935. Establishment of Medical College Regulations, 1999-Animal House. Medical Council of India Notification. New Delhi, the $18^{\text {th }}$ March, 2014 [No.MCI-34(41)/2013-Med./64020]. [document on the internet]. Available at: https://www.mciindia.org/documents/e_Gazette_Am endments/estt-new-med-col-regulation-1999.pdf

8. Ahirwar M, Sinha A, Shakya A, Kumar V. Computer Assisted Learning in Pharmacology: An Update. Alternatives to Animal Experiment Laboratory, Department of Pharmaceutical Engineering, Indian Institute of Technology (Banaras Hindu University), Varanasi-221 005, UP, India.

9. Glick SM. Animals for teaching purpose: medical students' attitude. Med Edu. 1995;29:39-42.

10. Medhi B, Sukhija M, Upadhayay S, Bhatia A, Anuradha K. Experimental teaching and interactive computer assisted learning: The student's viewpoint. JK Science, October-December 2005;7(4).

11. Dahanukar SA. Practical programme for MBBS students. Indian J Pharmacol. 1999;31:380-2.

12. Bhavsar VH, Vajpeyee SK, Joshi NJ, Mistry SD, Kantharia ND, Sharma AK, et al. Training during practical pharmacology sessions for undergraduate medical students: An experience with a modified teaching programme. Indian J Pharmacol 1999;31:176-86.

13. Bapna JS. Experience in teaching rational drug use. Indian J Pharmacol. 1993;25:2-4.

14. Hardin L, Patrick TB. Content review of medical educational software assessments. Medical Teacher. 1998;20:207-11.

15. Sethuraman KR. Computer assisted learning In: Srinivasa DK, Ananthakrishnan N, Sethuraman KR, Kumar S, editors. Medical education- principles and practice. National Teacher Training Centre, JIPMER, Pondicherry; 1995:77-81.

16. Horn LD, Radhakrishnan J, Saini S, Pepper GM, Peterson SJ. Evaluation of a computer program for teaching laboratory diagnosis of acid-base disorders. Computers in Biomedical Research. 1992;25:562-86.

Cite this article as: Kumar M, Kumar M, Mishra H, Manjhi PK, Chandra A, Mohan L, et al. Undergraduate medical students' perception regarding computer assisted learning in experimental pharmacology practical. Int J Basic Clin Pharmacol 2018;7:541-7. 


\section{APPENDIX I}

Student questionnaire on CAL (Computer Assisted Learning) and laboratory based Pharmacological practical.

Participation depends on your willingness. No personal information should be written on the paper (name, registration number). Please answer legibly and write the appropriate no. in boxes wherever required.

\section{Sex: $M / F$}

Nationality:

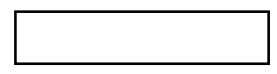

Medium of instruction at school: English/ Regional

Was Mathematics one of your subjects at school (10+2 level)? Yes/ No

Your attitude towards Mathematics at school: Liked it/Neutral/Hated it

Your attitude towards Chemistry at school: Liked it/Neutral/Hated it

Government selected/ self financing

For the following statements score using the following key: 1- Strongly Disagree (SD), 2- Disagree (D), 3-No Opinion (NO), 4-Agree (A), 5-Strongly Agree (SA)

\begin{tabular}{|c|c|c|c|c|c|c|}
\hline \multirow{2}{*}{$\begin{array}{l}\text { Sl. } \\
\text { No. }\end{array}$} & \multirow[b]{2}{*}{ Statements } & \multicolumn{5}{|c|}{ Key with Score } \\
\hline & & $\begin{array}{l}\text { SD } \\
(1)\end{array}$ & $\begin{array}{l}\text { D } \\
(2)\end{array}$ & $\begin{array}{l}\text { NO } \\
(3)\end{array}$ & $\begin{array}{l}\text { A } \\
(4)\end{array}$ & $\begin{array}{l}\text { SA } \\
(5)\end{array}$ \\
\hline 1) & $\begin{array}{l}\text { Computer simulation is more enjoyable and time saving than laboratory } \\
\text { practical }\end{array}$ & & & & & \\
\hline 2) & Computer simulation is easy to perform than laboratory practical & & & & & \\
\hline 3) & CAL is an effective method of teaching practical aspects & & & & & \\
\hline 4) & $\begin{array}{l}\text { Computer simulation contributes more to understanding theoretical } \\
\text { concepts viz. Terms, dose and concentration than laboratory practical }\end{array}$ & & & & & \\
\hline 5) & $\begin{array}{l}\text { In computer simulation no experimental error are seen as in laboratory } \\
\text { practical }\end{array}$ & & & & & \\
\hline 6) & $\begin{array}{l}\text { I would prefer to have done the experiment with computer simulation } \\
\text { than laboratory practical }\end{array}$ & & & & & \\
\hline 7) & CAL is a welcome change to routine practicals & & & & & \\
\hline 8) & Computer simulation is the best alternative to laboratory practical & & & & & \\
\hline 9) & $\begin{array}{l}\text { Effects of drugs demonstrated on animals like frogs and rabbits are } \\
\text { interesting }\end{array}$ & & & & & \\
\hline 10) & Many experiments can be demonstrated in a short time & & & & & \\
\hline
\end{tabular}

\section{APPENDIX II}

Feedback obtained from students regarding advantages of using CAL software to demonstrate drug effects by stating YES or NO.

\begin{tabular}{|lll}
\hline Si. No. & Statement & $\begin{array}{l}\text { Response } \\
\text { (YES/ NO) }\end{array}$ \\
\hline 1) & Avoids use of animals \\
\hline 2) & Drug effects can be visualised clearly \\
\hline 3$)$ & Exercises difficult to be conducted in the laboratory can be demonstrated using CAL \\
\hline 4$)$ & Many students can observe experiments at the same time \\
\hline 5$)$ & Experiments can be observed repeatedly without loss of animals \\
\hline 6$)$ & No experimental errors are seen as in laboratory exercises \\
\hline
\end{tabular}




\section{APPENDIX III}

Feedback obtained from students regarding disadvantages of using CAL software to demonstrate drug effects by stating YES or NO.

\begin{tabular}{|c|c|c|}
\hline Sl. No. & Statement & $\begin{array}{l}\text { Response } \\
\text { (YES/NO) }\end{array}$ \\
\hline 1) & No direct interaction with living tissue & \\
\hline 2) & Fun of making observation is missed & \\
\hline 3) & May easily forget details & \\
\hline 4) & Experiment is programmed with prefixed doses & \\
\hline 5) & Lack of interaction with live animals & \\
\hline 6) & Experiments performed in laboratory are easier to remember & \\
\hline 7) & Variations in response as observed in living tissue cannot be observed & \\
\hline 8) & Requires expertise to handle problems related to computers & \\
\hline 9) & Expensive method of teaching & \\
\hline 10) & Practical knowledge of how to do the experiment is lost & \\
\hline
\end{tabular}

